\title{
REFRACTORY BRADYCARDIA - A RARE COMPLICATION OF CARBOPROST TROMETHAMINE FOR INDUCTION OF ABORTION
}

\author{
Jasna Čerkez Habek ${ }^{1}$, Dubravko Habek ${ }^{2}$ and Dario Gulin ${ }^{1}$ \\ ${ }^{1}$ Department of Cardiology, Clinical Department of Internal Diseases, ${ }^{2} \mathrm{Clinical}$ Department of Obstetrics \\ and Gynecology, Sveti Duh University Hospital and Croatian Catholic University, Zagreb, Croatia
}

SUMMARY - We report a first case of refractory several-hour sinus bradycardia, a rare but already described side effect of intramuscular administration of carboprost tromethamine to induce abortion for medical indication in a patient without cardiovascular and other diseases. After administration of atropine sulfate $3 \times 0.5 \mathrm{mg}$ intravenously without effect, the patient's sinus rhythm spontaneously normalized as carboprost was eliminated from the body (it has a 3-hour half-life). It is reasonable to believe that the specific prostaglandin underlay the etiology of bradycardia.

Key words: Prostaglandins; Carboprost tromethamine; Bradycardia; Case reports

\section{Introduction}

The most common drugs in use for the induction of abortion and labor, as well as for curative obstetric hemorrhage are misoprostol, gemeprost, sulprostone, dinoprost and carboprost tromethamine. These drugs can be used either intravenously, intramuscularly, per $o s$, vaginally or rectally. Carboprost is a synthetic prostaglandin analogue of PGF2 that causes myometrial contractions by binding to the prostaglandin E2 receptor. The known side effects of exogenous prostaglandins are irritability, nausea, vomiting, diarrhea, coughing, dyspnea, asthma, hypertension, flushing, and pyrexia. Contraindications include obstructive lung disease and clinically relevant inflammatory disease. Cardiovascular side effects, albeit rare, mainly occur alongside cardiovascular collapse ${ }^{1-3}$.

We report a first case of refractory several-hour sinus bradycardia, a rare but already described side effect

Correspondence to: Prof. Jasna Čerkez Habek, MD, PhD, Department of Cardiology, Clinical Department of Internal Diseases, Sveti Duh University Hospital, Sveti Duh 64, HR-10000 Zagreb, Croatia

E-mail: jasna.habek@gmail.com

Received December 4, 2014, accepted November 23, 2015 of intramuscular administration of carboprost to induce abortion with medical indication.

\section{Case Report}

A 32-year-old pregnant woman was hospitalized at Department of Obstetrics because of preterm premature rupture of membranes (PPROM) with anhydramnios and intrauterine fetal death in $20^{\text {th }}$ week of gestation. Obstetric history revealed two pregnancies with two term births with normal neurocognitive development. The course of the current pregnancy was otherwise normal and microbiological cervical swabs were negative for pathogens. From the family history it was noted that her father had died from myocardial infarction, but her mother was healthy. Personal history was unremarkable; she works as a trader, denied drug use, and smoked 10 cigarettes per day prior to pregnancy. On admission, regular vital functions were recorded including normal temperature, pulse, and blood pressure. Laboratory tests (hematologic, coagulation, biochemical including $\mathrm{C}$-reactive protein) were within the reference range. Obstetric examination evaluated patency of the cervical canal to $2 \mathrm{~cm}$. Ultrasound confirmed the initial diagnosis. 
Given the findings, the patient was explained the possible risks of therapy and consent was obtained for the induction of labor with a $0.25 \mathrm{mg}$ intramuscular dose of the prostaglandin carboprost thromethamine (Prostin $15 \mathrm{M}^{\circledR}$, Pfizer). Antibiotic prophylaxis was achieved with ampicillin intravenous $1 \mathrm{~g} / 6 \mathrm{~h}$. Half an hour after the first injection of carboprost, the patient was cold, sweaty, weak, and felt urgent need to defecate.

With the help of a midwife, she went to the toilet but collapsed. The midwife could not palpate the pulse, and she lied the patient on the floor, put her in Trendelenburg's position, and called a doctor. Upon arrival, the doctor palpated pulse of $35 / \mathrm{min}$ on radial artery. The patient was somnolent, complaining of painless discomfort in the chest. Her vital parameters showed oxygen saturation of $90 \%$ and blood pressure of $90 / 50 \mathrm{~mm} \mathrm{Hg}$.

Immediate intravenous infusion of Ringer's lactate was administered, but she was still bradycardic. After 5 minutes, a $0.5 \mathrm{mg}$ dose of atropine was administered intravenously, successfully raising the pulse to $50 / \mathrm{min}$. The elevation in heart rate was only transient, as it dropped soon to $30 / \mathrm{min}$. The patient was administered $500 \mathrm{~mL}$ of colloid solution (HAES) and transferred to the Intensive Care Unit (ICU). In the ICU, her blood pressure was 100/60 $\mathrm{mm} \mathrm{Hg}$ and her electrocardiogram (ECG) showed sinus bradycardia of $30 / \mathrm{min}$. No other abnormalities, including abnormal atrioventricular conduction, were detected on ECG. Another 0.5 $\mathrm{mg}$ dose of atropine was administered intravenously. The possible embolic events and acute coronary syndrome were excluded by laboratory analysis of $\mathrm{D}$-dimer, troponin and creatine phosphokinase (MB fraction). One hour after arrival, repeat ECG still showed sinus bradycardia without any effect of three repeated $0.5 \mathrm{mg}$ doses of intravenous atropine. Blood pressure was maintained at $110 / 70 \mathrm{~mm} \mathrm{Hg}$ with the administration of colloids and crystalloids.

While in the ICU, the pregnant patient felt strong contractions and quickly delivered a dead embryo with the placenta en bloc. Ultrasound showed a blank empty uterine cavity and obstetric procedure ended. Prophylactic use of ampicillin was continued. Half an hour after delivery, a heart rate increase to $50 / \mathrm{min}$ was noted, and then to $60 / \mathrm{min}$ after one hour. Follow up laboratory findings were normal, except for mild leukocytosis to 12.3 (the possible side effect of prostaglandin). With continuous monitoring, the patient had no more episodes of bradycardia or hypotension. After 24-hour continuous ECG recording and echocardiographic examination, both of which were unremarkable, she was discharged with recommendation to do clinical examination after one month. Follow up cardiologist examination performed one month later showed normal cardiac status.

\section{Discussion}

The effects of prostaglandins on the cardiovascular system are rare, but can be dramatic. Bradycardia and hypotension caused by exogenous prostaglandin was described in experimental pharmacology (e.g., on cats), and the mentioned complications were inhibited by use of meclofenamic acid ${ }^{4}$. Hainsworth ${ }^{5}$ has described the possible pathophysiological mechanism of bradycardia and hypotension on endogenous bradykinin and prostaglandins due to the effects on chemosensitive ventricular mechanoreceptors and coronary baroreceptors. Hintze ${ }^{6}$ has described vasoactive effects of prostaglandin with reflex bradycardia and hypotension due to stimulation of cardiac receptors predominantly in the inferoposterior wall of the left ventricle.

Vagal bradycardia as an effect of prostaglandins due to activation of cardiac reflex sensitivity to myocardial ischemia has been described by StaszewskaBarczak $^{7}$. However, only a few papers describe the negative cardiovascular effects of prostaglandins in obstetrics. Vasospastic angina pectoris with bradycardia after induction of labor with mifepristone and gemeprost in pregnant women with migraine and smoking history has been described by Lindhardt et al. ${ }^{1}$. The authors suggest taking careful history of the possible vasospastic disease in women as the prevention of serious cardiac complications.

Two works report on cardiac arrest after administration of sulprostone. In the first one, arrest occurred upon the intravenous use of sulprostone after cesarean section due to postpartum hemorrhage with successful resuscitation. The authors emphasize the potential impact of sulprostone on coronary spasm, bradycardia, and asystole ${ }^{2}$. The other describes cardiac arrest in a 39-year-old woman in labor after the application of sulprostone into the uterine cavity because of postpartum hemorrhage following manual removal of the placenta. Resuscitation took a long time, but was successful. Evidence in the literature suggests that sulprostone 
is contraindicated in women who are older than 35 years, smoke, or have other cardiovascular risk factors ${ }^{3}$.

With the exception of smoking outside of pregnancy, our patient had no major risk factors for developing cardiovascular side effects. Considering that the patient's sinus rhythm spontaneously normalized as carboprost was eliminated from the body (it has a 3-hour half-life), it is reasonable to believe that the specific prostaglandin underlay the etiology of bradycardia.

\section{References}

1. Lindhardt TB, Walker LR, Colov NS, Hansen PS. Vasospastic angina pectoris following abortion induced by prostaglandin analogue. Ugeskr Laeger. 2000;162:6536-7.
2. Lampati L, Colantonio LB, Calderini E. Cardiac arrest during sulprostone adminisatration - a case report. Acta Anaesthesiol Scand. 2013;57:395-7.

3. Beerendonk CC, Massuger LF, Lucassen AM, Lerou JG, van den Berg PP. Circulatory arrest following sulprostone administration in postpartum hemorrhage. Ned Tijdschr Geneeskd. 1998;142:195-7.

4. Koss MC, Nakano J, Rieger JA. Inhibition of prostaglandin F2 alpha-induced reflex bradycardia and hypotension by meclofenamic acid. Prostaglandins. 1976;11:691-8.

5. Hainsworth R. Cardiovascular reflexes from ventricular and coronary receptors. Adv Exp Med Biol. 1995;381:157-4.

6. Hintze TH. Reflex regulation of the circulation after stimulation of cardiac receptors by prostaglandins. Fed Proc. 1987; 46:73-80.

7. Staszewska-Barczak J. Prostanoids and cardiac reflexes of sympathetic and vagal origin. Am J Cardiol. 1983;52:36A-45A.

Sažetak

\section{REFRAKTORNA BRADIKARDIJA - RIJETKA KOMPLIKACIJA KARBOPROST TROMETAMINA ZA INDUCIRANJE POBAČAJA}

\section{J. Čerkez Habek, D. Habek i D. Gulin}

Autori prikazuju prvi slučaj refraktorne višesatne sinusne bradikardije, rijetke komplikacije intramuskularne aplikacije karboprost trometamina za induciranje pobačaja iz medicinske indikacije u bolesnice bez srčanožilnih i ostalih bolesti. Nakon davanja $3 \times 0,5 \mathrm{mg}$ atropin sulfata intravenski učinak je izostao, no ritam se spontano normalizirao u sinusni nakon tri sata, što se može smatrati kao vrijeme poluraspada prostaglandina i njegova rijetkog učinka na srčanožilni sustav.

Ključne riječi: Prostaglandin; Karboprost trometamin; Bradikardija; Prikazi slučaja 